\title{
СТАТИСТИЧНЕ ОБГРУНТУВАННЯ КОМПЕНСАТОРНИХ МЕХАНІЗМІВ ЕПІТЕАІЮ ЯСЕН В УМОВАХ НІКОТИНОВОЇ ІНТОКСИКАЦІї
}

H. В. Гасюк

\author{
АВНЗ "Тернопільський державний медичний університет \\ імені І. Я. Горбачевського МОз України"
}

\begin{abstract}
В статті наведені результати комплексного статистичного обґрунтування компенсаторних механізмів перебудови епітелію ясен за умов нікотинової інтоксикації. Отримані дані дають можливість характеризувати описані цитоспецифічні зміни як тенденцію до розвитку незавершеного зроговіння, про що свідчить вірогідне збільшення кількості поверхневих клітин на тлі зменшення кількості рогових цусочок. Поява в цитограмах парабазальних епітеліоцитів характеризує активацію компенсаторних механізмів епітелію в умовах нікотинової інтоксикації.
\end{abstract}

Ключові слова: ясна, епітелій, клітини, ядро, цитоплазма.

\section{СТАТИСТИЧЕСКОЕ ОБОСНОВАНИЕ КОМПЕНСАТОРНЫХ МЕХАНИЗМОВ ЭПИТЕАИЯ АЕСЕН В УСАОВИЯХ НИКОТИНОВОЙ ИНТОКСИКАЦИИ}

Н. В. Гасюк

\author{
ГВУЗ "Тернопольский государственный медицинский университет
} имени И.Я. Горбачевского МЗ Украины"

\begin{abstract}
В статье приведены результаты комплексного статистического обоснования компенсаторных механизмов перестройки эпителия десен в условиях никотиновой интоксикации. Полученные данные дают возможность характеризовать цитоспецифические изменения как тенденцию к развитию незавершенного ороговения, о чем свидетельствует достоверное увеличение количества поверхностных клеток на фоне уменьшения количества роговых чешуек. Появление в цитограммах парабазальных эпителиоцитов характеризует активацию компенсаторных механизмов эпителия в условиях никотиновой интоксикации.
\end{abstract}

КАючевые слова: Аесна, эпителий, клетки, ядро, цитоплазма.

\section{STATISTICAL FOUNDATIONS OF COMPENSATORY MECHANISMS OF EPITHELIUM UNDER NICOTINE GUM INTOXICATION}

\author{
N. V. Gasyuk
}

SHEI "Ternopil State Medical University by I. Ya. Horbachevsky of MPH of Ukraine"

In the article the results of a comprehensive statistical study of compensatory mechanisms of restructuring epithelium nicotine gum under conditions of intoxication. The results make it possible to characterize changes cytospecific described as a tendency to develop incomplete keratinization, as evidenced virohidnene increase in the number of surface cells on the background of reduction of horny scales. The appearance in cytohrams parabasal epithelial cells ch aracterizes activation of compensatory mechanisms in epithelial conditions nicotine intoxication.

Key words: gingiva, epithelium, cells, nucleus, cytoplasm.

Робота є фрагментом проекту науково-дослідного інституту генетичних та імунологічних основ розвитку патології та фармакогенетики (м. Полтава) «Роль запальних захворювань зубощелепного апарату в розвитку хвороб, пов'язаних із системним запаленням», номер державної реєстрації № 0112U0011538. Автор є співвиконавцем даного проекту.
Вступ. В теперішній час науково обгрунтованою $\epsilon$ думка про те, що запальні захворювання пародонта розвиваються під впливом як місцевих причин, так i загальних факторів, на тлі зміненої реактивності організму. Одним із поширених місцевих факторів ризику в етіології запальних захворювань тканин пародонта є куріння [2]. 
Поширеність куріння в Україні складає приблизно $65 \%$ серед чоловіків, близько $30 \%$ - серед жінок і $50 \%$ - серед хлопчиків і дівчаток старших класів. Слід зазначити, що показники за останні 5-10 років зросли в 2-3 рази [3].

Куріння є однією із найпоширеніших шкідливих звичок, яка призводить до впливу на тканини слизової оболонки порожнини рота і пародонта речовин, які вміщують близько 4 тисяч активних сполук, здатних провокувати специфічні зміни як слизової і тканин пародонта, так і твердих тканин зубів [8, 9].

Основний ефект куріння пов'язують із активацією бактеріальної агресії і підвищенням утворення мікробних бляшок, зубного нальоту та зубного каменю [7].

В іноземній літературі є поодинокі повідомлення стосовно впливу тютюнового диму на розлади мікроциркуляції, однак вони небагаточисельні, і це дає можливість стверджувати, що механізми впливу куріння на розвиток патологічних процесів даної анатомічної локалізації чітко не з'ясовані [6].

Тенденція до стрімкого збільшення відсотка курців серед осіб молодого віку обох статей ставить нові завдання перед пародонтологами і фахівцями із патології слизової оболонки порожнини рота. Поширеність захворювань пародонта, згідно з більшістю спостережень, вища у курців i, в свою чергу, серед хворих на генералізований пародонтит, курці переважають $[4,5,11]$.

Однак, при досить великому масиві досліджень стосовно впливу куріння, в зарубіжній літературі в доступних джерелах, роботи комплексного характеру, які дозволяють скласти цілісну картину впливу куріння на слизову оболонку порожнини рота та тканини пародонта, відсутні. У вітчизняній літературі такі дані практично не зустрічаються.

В зв'язку з цим, актуальним є питання вивчення змін диференціації епітелію ясен під впливом куріння.

Метою дослідження стало визначення причиннонаслідкових зв'язків компенсаторних механізмів епітелію ясен в умовах нікотинової інтоксикації шляхом комплексного статистичного аналізу.
Матеріал і методи дослідження. Матеріалом для дослідження слугував ясенний епітелій, забраний у 25 осіб чоловічої статі молодого віку. Основним критерієм відбору серед даного контингенту були: наявність шкідливої звички - куріння, тривалість якого не перевищувала термін 1-3 роки, та відсутність супутньої соматичної патології. Епітелій забирали шпателем з подальшим перенесенням на предметне скло і висушуванням при відкритому доступі повітря впродовж 3-5 хвилин. Забарвлення матеріалу проводили за Гімзою-Романовським, 3 подальшим мікроскопічним і морфологічним аналізом, з урахуванням процентного співвідношення різних форм епітеліоцитів в нормі.

Статистичні методи дослідження виконані у відділі статистичних досліджень ДВНЗ «Тернопільський державний медичний університет імені I. Я. Горбачевського МО3 України». Параметричні методи застосовували для показників, розподіл яких відповідав вимогам нормальності. Для оцінки характеру розподілу визначали коефіцієнт асиметрії та ексцес. Перевірку нормальності проводили за тестом асиметрії Шапіро-Уїлка. Достовірність відмінностей отриманих результатів для різних груп визначали за допомогою t-критерію Стьюдента. Відмінності вважали достовірними за загальноприйнятою в медико-біологічних дослідженнях ймовірністю помилки $\mathrm{p}<0,05$. Імовірність помилки оцінювали за таблицями Стьюдента з урахуванням розміру експериментальних груп. У випадках, коли закон розподілу статистично достовірно відрізнявся від нормального, розраховували непараметричний критерій (U) Манна-Уїтні як непараметричний аналог t-критерію Стьюдента.

Результати й обговорення. Проведеними нами дослідженнями, визначено наявність в цитограмах парабазальних, проміжних і поверхневих клітин, а також рогових лусочок. Встановлено достовірне збільшення кількості поверхневих епітеліоцитів, порівняно із цитограмами контрольної групи на тлі зменшення кількості рогових лусочок (табл. 1).

Таблиця 1. Середні значення відсоткового співвідношення різних класів клітин багатошарового плоского епітелію щоки та ясен осіб чоловічої статі молодого віку (курців)

\begin{tabular}{|c|c|c|c|c|}
\hline \multirow{2}{*}{$\begin{array}{c}\text { Анатомічна } \\
\text { ділянка СОПР }\end{array}$} & \multicolumn{3}{|c|}{ Клітини мазків } \\
\cline { 2 - 5 } & парабазальні & проміжні & поверхневі & рогові лусочки \\
\hline Норма & 0 & $59,2 \pm 1,15$ & $7,6 \pm 0,34$ & $33,2 \pm 0,65$ \\
\hline Ясна & $8,2 \pm 0,53$ & $58,7 \pm 1,16$ & $11,2 \pm 0,44^{*}$ & $21,9 \pm 1,18^{*}$ \\
\hline
\end{tabular}

Примітка. * - $<<0,05$ порівняно з нормою. 
Парабазальні епітеліоцити характеризуються стереотипністю клітинної організації, яка є специфічною для даного етапу диферону епітеліальної кліти- ни. Цитоплазма клітин базофільна, із наявністю видовжених фрагментів (рис. 1).

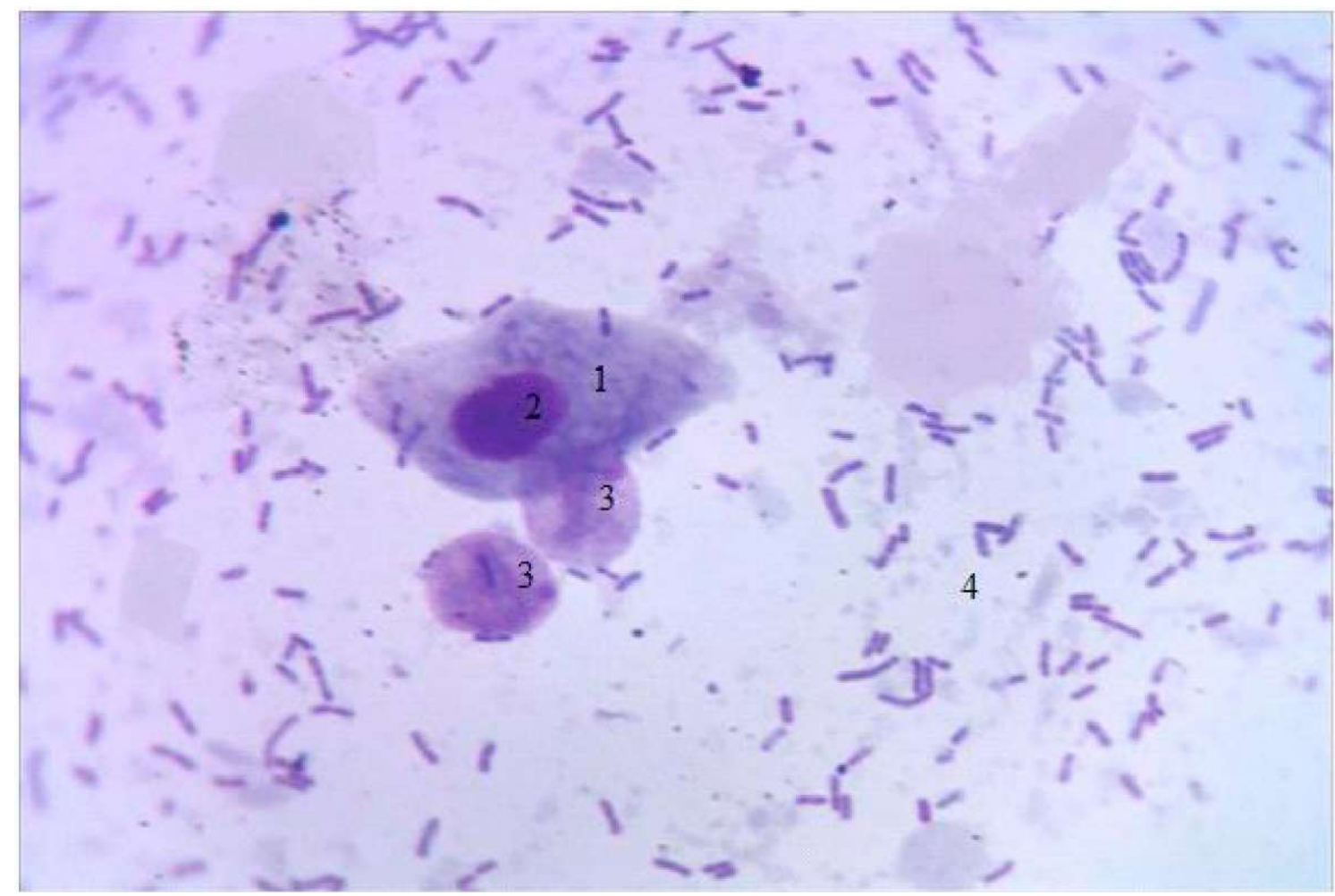

Puc. 1. Цитограма ясен. Забарвлення: за Гімзою-Романовським. Збільшення: х400.

1 - парабазальний епітеліоцит; 2 - ядро клітини; 3 - сегментоядерні лейкоцити; 4 - палички.

При цьому слід відзначити наявність у цитограмах сегментоядерних лейкоцитів, здебільшого фагоцитарно активних.

Будова проміжних клітин характеризувалася стереотипністю, проте з метою визначення зміни тинкторіальних властивостей клітин проміжного шару нами проведено ідентифікацію за допомогою ШЙКреакції із дозабарвленням йодною кислотою. Цей тест дає можливість ідентифікувати в цитоплазмі клітин глікопротеїдів та їх метаболітів, за умов впливу на неї реактиву Шифа з наступною обробкою йодною кислотою.

У результаті проведеного нами тесту цитоплазма проміжних клітин набула яскраво пурпурового забарвлення, що дає можливість стверджувати про ініціацію нікотином гліколітичних процесів у епітеліоцитах, оскільки, як показали наші попередні результати, глікоген в епітеліоцитах ясен в нормі візуалізується в незначній кількості або повністю відсутній (рис. 2).

Будова поверхневих клітин, як еозинофільних, так і базофільних, також є стереотипною. Проте дещо змінюється форма, втрачається чіткість контурів плазмолеми та з'являється узурованість. У цитоплазмі еозинофільних клітин візуалізуються поодинокі еозинофільні гранули. Ядра здебільшого пікнотичні.

Рогові лусочки дещо менших розмірів, порівняно із ідентичними в цитограмах норми, кількість їх в порівнянні також достовірно зменшилась (рис. 3). Доволі активною є контамінація мікроорганізмів на поверхневих ясенних епітеліоцитах, що, на нашу думку, пояснюється наступним положенням. А саме, впливом нікотину на адгезивну здатність клітин даного класу за рахунок підвищення активності гліколітичних процесів. Численну колонізацію мікробного складу можна розглядати як прогностичний чинник виникнення захворювань тканин пародонта у обстеженого контингенту осіб, оскільки результати досліджень закордонних науковців [9, $10]$, які грунтуються на численних імунологічних та мікробіологічних дослідженнях, відзначають переважно інфекційне походження генералізованого пародонтиту. 


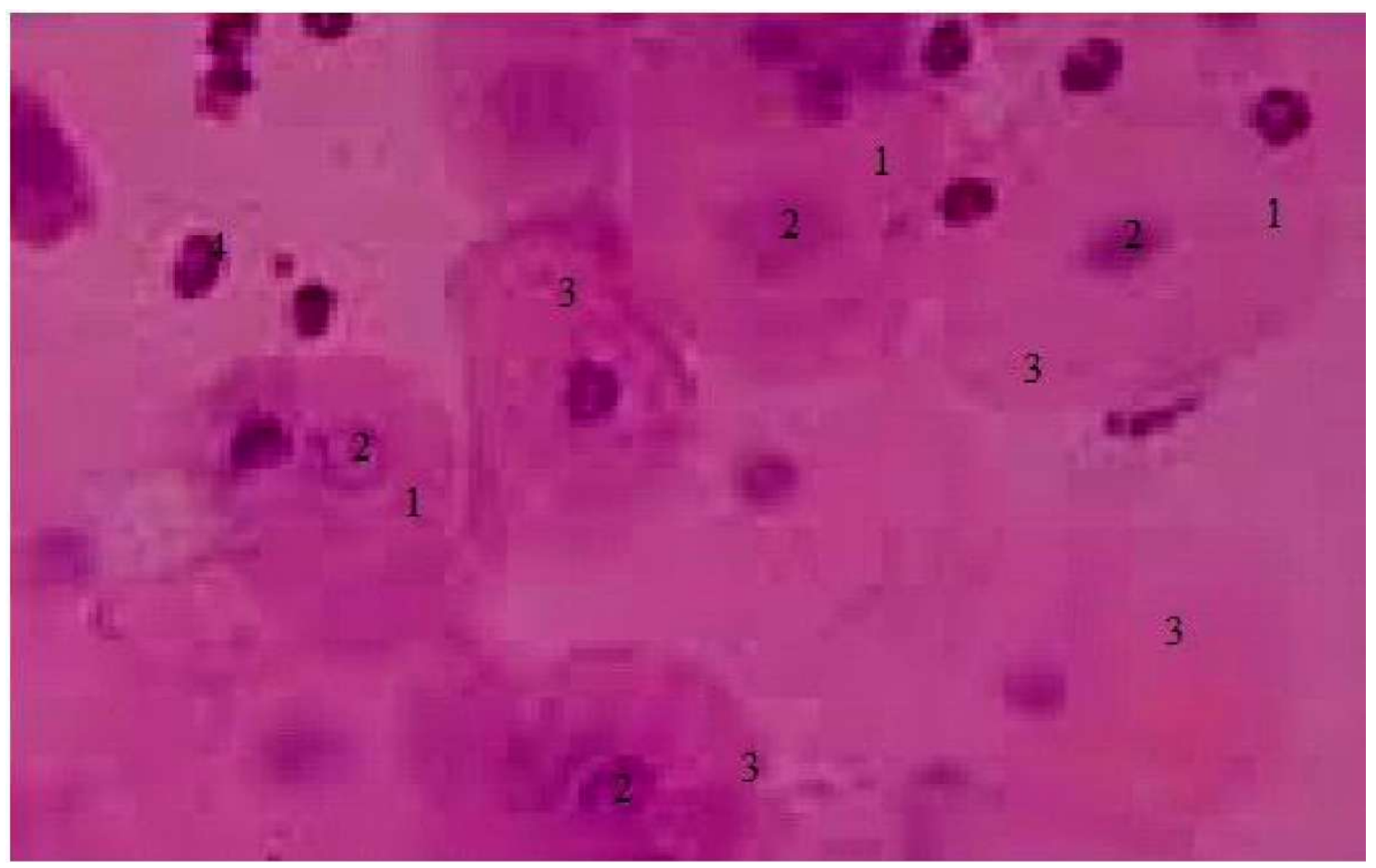

Puc. 2. Цитограма ясен. Забарвлення: суміш реактивів Шифа-йодна кислота. Збільшення: х1000. 1 - проміжні епітеліоцити; 2 - ядра; 3 - ШЙК-позитивна гомогенна цитоплазма.

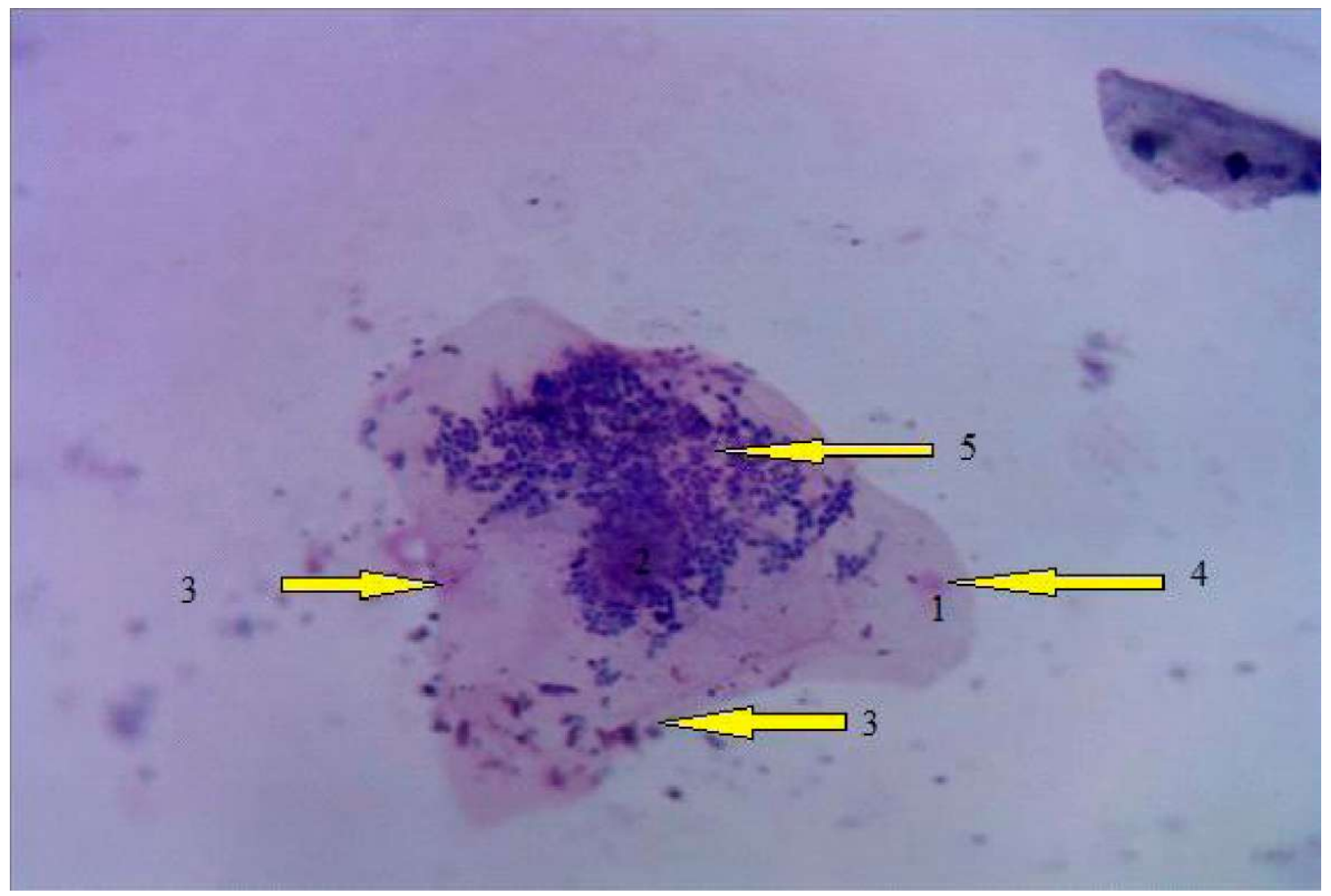

Puc. 3. Цитограма ясен. Забарвлення: за Гімзою-Романовським. Збільшення: х400.

1 - поверхнева клітина; 2 - пікноз ядра; 3 - узурація плазмолеми; 4 - поодинокі еозинофільні гранули; 5 - мікробна контамінація. 
Статистичний аналіз цитограм дав можливість визначення наступного відсоткового співвідношення клітин ясенного епітелію у осіб обстеженого контингенту, залежно від ступеня їх диференціації. Для ясен дане співвідношення складає: $(8,2 \pm 0,53)$ : $(58,7 \pm 1,16):(11,2 \pm 044):(21,9 \pm 1,18)$.

Отримані результати відрізняються від відсоткового співвідношення диференціації епітеліоцитів багатошарового плоского епітелію ясен в нормі [1], та співвідношення, визначеного нами для осіб обстеженого контингенту із урахуванням віку та статі, в сторону порушення зроговіння даної анатомічної ділянки за умов впливу нікотину.

Висновки. Результати проведених нами досліджень вказують на тенденцію до розвитку незавершеного зроговіння, про що свідчить достовірне

\section{Література}

1. Быков В. Л. Функциональная морфология эпителиального барьера слизистой оболочки полости рта / В. Л. Быков // Стоматология. - 1997. - № 3. - С. 12-17.

2. Грудянов А. И. Заболевания пародонта / А. И. Грудянов. - М. : Медицинское информационное агентство, 2009. - $336 \mathrm{c}$.

3. Табачніков С. I. Поширеність тютюнопаління та тютюнової залежності в різних країнах світу / С. І. Табачніков, I. С. Риткіс // Сучасні препарати та нанотехнології. 2013. - № 7 (103). - C. 35-41.

4. Davis G. Accessible sialic acid content of oral epithelial cells from healthy and gingivitis subjects / G. Davis, R. G. Gibbons // J. Periodontal. Res. - 1990. - № 25. - P. 250 - 253 .

5. Kornman K. S. The «innovator's dilemma» for periodontists / K. S. Kornman, D. Clem // J. Periodontal. - 2010. - Vol. 81, № 5. - P. 646-649.

6. Lova R. M. Morphologic changes in the microcirculation induced by chronic smoking habit: a videocapillaroscopic study on the human labial mucosa / R. M. Lova // Am. Heart. J. - 2002. - № 143 (4) - P. 658-662 . збільшення кількості поверхневих клітин на тлі зменшення кількості рогових лусочок. Поява в цитограмах парабазальних епітеліоцитів характеризує активацію компенсаторних механізмів епітелію в умовах нікотинової інтоксикації. Літературними джерелами показано, що розподіл частоти мітозів між базальними та парабазальними епітеліоцитами ясен людини складає $23: 77$ із перевагою частоти в останніх [1].

Перспективи подальших досліджень. В подальшому плануємо визначення патогенетичних механізмів виникнення генералізованого пародонтиту через поліморфізм ядерного фактора транскрипції

$\mathrm{NFkB} 1$, який контролює експресію генів імунної відповіді, апоптозу і клітинного циклу.

7. Mirbod S. M. Tobacco-associated lesions of the oral cavity: Part I. Nonmalignant lesions / S. M. Mirbod, S. I. Ahing // Can. Dent. Assoc. - 2000. - № 66 (5). - P. 58-62.

8. Population-based study of salivary carriage of periodontal pathogens in adults / E. Kononen, S. Paju, P. J. Pussinen, M. Hyvonen // J. Clin. Microbiol.- 2007. - Vol. 45, № 8.P. 2446-2451.

9. Schmalz G. Release of prostaglandin E2, IL-6 and IL-8 from human oral epithelial culture models after exposure to compounds of dental materials / G. Schmalz, H. Schweiki, K. A. Hiller// Eur. J. Oral. Sci. - 2000. - № 108. - P. 442448.

10. Schwartz J. L. Oral cytology assessment by flow cytometry of DNA adducts, aneuploidy, proliferation and apoptosis shows differences between smokers and non-smokers / J. L. Schwartz // Oral Oncol. - 2003. - № 39 (8). - P. 842854 .

11. Van Dyke T. E. Inflammation and factors that may regulate inflammatory response / T. E. Van Dyke, K. S. Kornman // J. Periodontal. - 2008. - Vol. 79, № 8. - P. 1503-1507. 